\title{
ANALISIS KEBUTUHAN PENGEMBANGAN LEMBAR KERJA SISWA (LKS) BERBASIS PROBLEM BASED LEARNING PADA MATERI ELASTISITAS DAN HUKUM HOOKE KELAS XI DI SMA NEGERI 1 PALANGKA RAYA
}

\author{
Devi Vitrianingsih ${ }^{1}$, Hadma Yuliani ${ }^{2}$, Nur Inayah Syar $^{3}$, Muhammad Nasir ${ }^{4}$ \\ 1,2,3,4 Institut Agama Islam Negeri Palangka Raya \\ ${ }^{1}$ devivitrianingsih@gmail.com, ${ }^{2}$ hadma.yuliani@iain-palangkaraya.ac.id, \\ ${ }^{3}$ nur.inayah.syar@iain-palangkaraya.ac.id, ${ }^{4}$ nasir@iain-palangkaraya.ac.id
}

\begin{abstract}
Analysis Of The Student Worksheet (LKS) Based Problem Learning On Elasticity And Law Of Hooke Materials in Class XI SMA Negeri 1 Palangka Raya: The purpose of this research: 1) identify the learning media used by teachers in teaching physics learning materials; 2) identifying the material needed to be developed in studying Hooke's law and elasticity; 3) describe the analysis of the need for development of a student worksheet (LKS) problem based learning in class of elasticity materials and Hooke's law. The type of research that is done is quantitative and qualitative (combined). The type of approach used is a descriptive approach. The development methods used to develop products are research and development methods $(R \& D)$ with ADDIE development models. The method of analysis used is qualitative descriptive analysis. The completion of the this research was concluded that; 1) the learning media used by teachers to teach physics learning materials include the package books, the LKS, modules, and other online learning applications; 2) the teaching LKS based on problem solving particularly in Hooke's law and elasticity materials needed to be developed in order to train critical thinking ability in students; 3) as many as 55\% students say do not use LKS for perform practical activities, $78 \%$ of students say require interesting worksheets, and $92 \%$ of students say require development of LKS based on problem solving.
\end{abstract}

Keywords: student worksheet, problem solving

Abstrak: Analisis Kebutuhan Pengembangan Lembar Kerja Siswa (LKS)
Berbasis Problem Based Learning Pada Materi Elastisitas Dan Hukum Hooke
Kelas XI Di SMA Negeri 1 Palangka Raya. Penelitian ini bertujuan untuk: 1)
mengidentifikasi media pembelajaran yang digunakan guru dalam mengajarkan
materi pembelajaran fisika; 2) mengidentifikasi bahan ajar yang perlu
dikembangkan untuk mempelajari materi elastisitas dan hukum Hooke; 3)
mendeskripsikan kebutuhan pengembangan lembar kerja siswa (LKS) berbasis
problem based learning di kelas XI materi elastisitas dan hukum Hooke. Jenis
penelitian yang dilakukan adalah penelitian kuantitatif dan kualitatif (gabungan). 
Jenis pendekatan yang digunakan adalah pendekatan deskriptif. Metode pengembangan yang digunakan untuk mengembangkan produk adalah metode research and development $(\mathrm{R} \& \mathrm{D})$ dengan model pengembangan ADDIE. Metode analisis yang digunakan adalah analisis deskriptif kualitatif. Hasil penelitian dapat disimpulkan bahwa; 1) media pembelajaran yang digunakan oleh guru untuk mengajarkan materi pembelajaran fisika antara lain: Buku paket, LKS, modul, dan aplikasi pembelajaran online lainnya; 2) bahan ajar berupa LKS berbasis pemecahan masalah khususnya pada materi elastisitas dan hukum Hooke perlu dikembangkan guna melatih keterapilan berpikir kritis siswa;. 3) sebanyak 55\% siswa mengatakan tidak menggunakan LKS untuk melakukan kegiatan praktikum, sebanyak $78 \%$ siswa mengatakan membutuhkan LKS yang menarik, dan sebanyak $92 \%$ siswa mengatakan memerlukan pengembangan LKS berbasis pemecahan masalah.

Kata kunci: lembar kerja siswa, pemecahan masalah

Salah satu faktor keberhasilan pendidikan adalah kurikulum (Winarno, 2012). Kurikulum adalah seperangkat rencana dan pengaturan mengenai tujuan, isi, dan bahan pelajaran serta cara yang digunakan sebagai pedoman penyelenggaraan kegiatan pembelajaran untuk mencapai tujuan pendidikan tertentu (Kemendikbud, 2013). Tujuan tertentu ini meliputi tujuan pendidikan nasional serta kesesuaian dengan kekhasan, kondisi dan potensi daerah, satuan pendidikan dan peserta didik (Zaini, 2015). Dalam satuan pendidikan, kurikulum bersifat dinamis yakni selalu dilakukan perubahan dan pengembangan menyesuaikan perkembangan dan tantangan zaman (Mulyasa, 2014). Meski demikian, perubahan dan pengembangan kurikulum harus dilakukan dengan sistematis dan terarah, dimana visi dan arahnya jelas akan dibawa kemana system pendidikan nasional dengan kurikulum tersebut (Mustafa \& Dwiyogo, 2020). Di Indonesia telah terjadi beberapa kali perubahan kurikulum pendidikan. Hal tersebut terjadi karna adanya tuntutan zaman sehingga diharapkan dapat mencetak generasi yang baik di masa depan.

Saat ini kurikulum yang diterapkan adalah kurikulum 2013, yakni hasil penyempurnaan dari kurikulum sebelumnya KTSP (Zaini, 2015). Kurikulum 2013 disiapkan untuk mencetak generasi yang siap di dalam menghadapi masa depan (Kristiantari, 2014). Kurikulum 2013 lebih berorientasi kepada pemberntukan karakter peserta didik yang ditinjau dari sikap spiritual, sikap social (afektif), pengetahuan (kognitif), dan keterampilan (psikomotorik) (Mustafa \& Dwiyogo, 2020). Pentingnya pendidikan karakter sebagai upaya dalam peningkatan seluruh perilaku peserta didik. Perilaku yang dimaksud mencakup adat istiadat, nilai- nilai, potensi, kemampuan, bakat, dan pola pikir peserta didik (Wiliyanti, Suyanto, \& Abdurrahman, 2014). Selain itu, kurikulum 2013 juga menuntut keaktifan peserta didik dalam proses pembelajaran dan berpusat pada peserta didik (Permana, 2015). Oleh karena itu peserta didik harus dilatih untuk mampu memiliki keterampilan berpikir kritis, kreatif, komunikatif, dan kolaboratif yang biasa dikenal dengan sebutan 4C (Critical thinking and problem solving, Creativity, Communication, and Collaboration) (Meiwandari, 2020).

Mengatasi dari hal-hal tersebut maka perlu dikembangkan salah satu kemampuan dalam diri peserta didik yakni pemecahan masalah (Mastang, 2017). Keterampilan pemecahan masalah dapat dilatih dan didukung dengan pembelajaran yang dapat mendorong peserta didik untuk aktif mencari solusi dari permasalahan yang diberikan (Mastang, 2017). Hal ini dapat diawali dengan perencanaan pembelajaran yang baik, oleh karena itu diperlukan bahan ajar yang mendukung peserta didik untuk melatih keterampilan memecahkan masalah. Agar memiliki nilai kegunaan yang lebih maka penyusunan lembar kerja berbasis 
masalah harus menarik perhatian siswa, sehingga dengan adanya lembar kerja berbasis masalah tersebut dapat menarik minat dan motivasi siswa dalam mempelajari materi fisika (Nindyasafitri, Serevina, \& Rustana, 2017).

\section{METODE}

Penelitian ini termasuk dalam penelitian kuantitatif dan kualitatif (mix method research) atau penelitian gabungan. Penelitian gabungan (mix method research) merupakan salah satu metode penelitin yang digunakan apabila peneliti memiliki pertanyaan yang perlu diuji dari segi outcomes dan prosesnya, serta menyangkut metode kuantitatif dan kualitatif dalam satu penelitian (Masrizal, 2012) Jenis penelitian yang digunakan adalah penelitian deskriptif, yaitu penelitian yang berusaha mendeskripsikan, menggambarkan, melukiskan fenomena yang terjadi secara nyata, realistik, aktual, sistematis, faktual, dan akurat mengenai fakta-fakta, sifatsifat serta hubungan antar fenomena yang sedang diamati (Mustafa \& Dwiyogo, 2020) (Mustafa \& Dwiyogo, 2020) (Rukajat, 2018).

Metode pengembangan yang digunakan dalam penelitian ini adalah metode penelitian dan pengembangan $(R \& D)$ dengan model ADDIE (analysis, design, development, implementation, and evaluation). Model penelitian ADDIE merupakan proses instruksional yang terdiri dari lima fase, yaitu; analysis (analisis); design (perancangan), development (pengembangan dan pengujian); implementation (pengunaan); dan evaluation (evaluasi) (Cahyadi, 2019). Namun penelitian ini dibatasi hanya sampai tahap analysisis (analisis), yaitu mendefinisikan kebutuhan siswa dalam menggunakan bahan ajar berupa Lembar Kerja Siswa (LKS) khususnya untuk mempelajari fisika materi elastisitas dan hukum Hooke.

Teknik pengumpulan data yang dilakukan dalam penelitian ini adalah metode wawancara terhadap guru fisika SMA kelas XI untuk mengetahui penggunaan bahan ajar dalam mempelajari materi fisika, dan metode angket untuk mengetahui permasalah yang dialami siswa terkait bahan ajar yang digunakan. Angket analisis kebutuhan disebarkan secara online dalam bentuk platform google form kepada siswa kelas XI di SMA Negeri 1 Palangka Raya yang berjumlah 77 orang.

\section{HASIL DAN PEMBAHASAN}

Berdasarkan hasil wawancara dengan salah satu guru fisika di SMA Negeri 1 Palangka Raya didapatkan hasil bahwa guru jarang memberikan lembar kerja kepada siswa. Lembar kerja yang digunakan oleh guru masih terbatas pada lembar kerja yang telah tersedia di buku paket pegangan guru dan siswa. Sehingga hal ini membuat guru tidak membuat lembar kerja sendiri untuk siswa. Lembar kerja yang tersedia pada buku paket sudah mengarahkan siswa untuk memecahkan masalah, namun umumnya lembar kerja yang diberikan menuntut siswa untuk melakukan praktikum agar dapat memecahkan masalah sehingga ini menjadi hambatan juga untuk guru dalam memberikan lembar kerja tersebut.

Penelitian ini dilakukan dengan menyebarkan angket analisis kebutuhan secara online dalam bentuk platform google form kepada siswa kelas XI di SMA Negeri 1 Palangka Raya. Pembelajaran yang dilakukan oleh siswa kelas XI di SMA Negeri 1 Palangka Raya berbasis online (daring) dengan berbantukan aplikasi whatsapp serta aplikasi pembelajaran lainnya seperti google classroom, google form, zoom, dan aplikasi lainnya yang menunjang pembelajaran online. Namun faktanya, sistem pembelajaran online yang diterapkan membuat siswa merasa kesulitan dalam proses pembelajaran, khususnya dalam mempelajari materi fisika. Kesulitan siswa mengenai sistem pembelajaran yang dilakukan saat ini digambarkan pada diagram berikut:

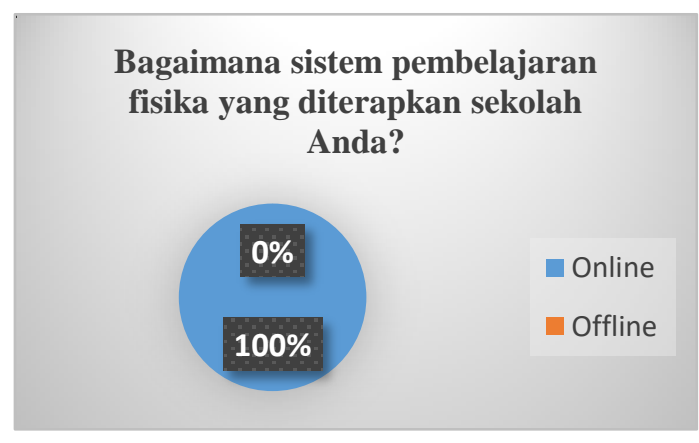

Gambar 1. Diagram respon siswa terhadap sistem pembelajaran yang diterapkan sekolah 
Diagram 1 diatas menunjukkan sebanyak $100 \%$ siswa menyatakan bahwa sistem pembelajaran yang dilakukan saat ini sulit. Kesulitan yang dialami siswa dalam pembelajaran online diakibatkan oleh beberapa faktor misalnya seperti jaringan internet yang belum stabil dan sulitnya memahami penjelasan guru secara online. Hal ini sejalan dengan penelitian yang dilakukan oleh (Sidiq et al, 2020) yang menyatakan bahwa siswa mengalami kendala selama pembelajaran daring diantaranya memahami materi disampaikan guru secara online, dan paket internet serta jaringan internet yang kurang mendukung.

Kendala yang dialami siswa berdampak pada proses pembelajaran fisika. Siswa merasa kesulitan dalam mempelajari materi fisika. Hal tersebut dapat dilihat dari diagram dibawah ini:

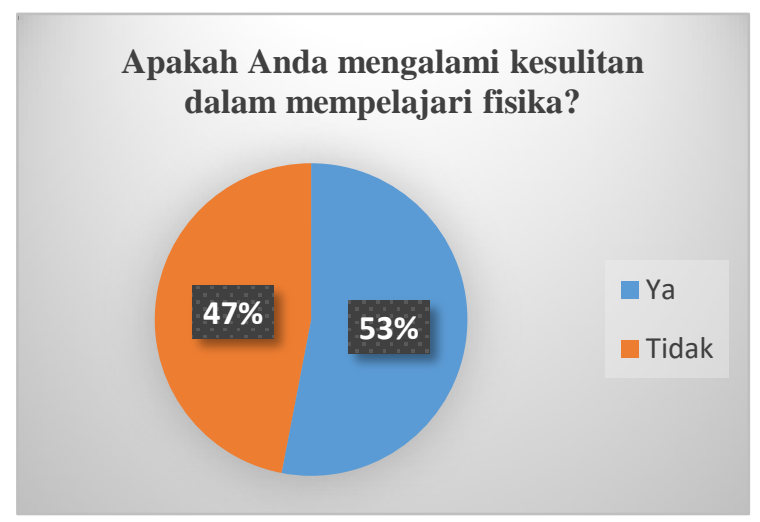

Gambar 2. Diagram respon siswa terhadap pembelajaran fisika

Berdasarkan diagram 2 diatas, sebanyak $53 \%$ siswa menyatakan kesulitan dalam mempelajari materi fisika. Selain karna banyaknya rumus yang harus dimengerti, penjelasan guru serta sumber belajar yang digunakan sulit dimengerti oleh siswa terutama saat pembelajaran berbasis daring. Hal ini tentunya memerlukan media pembelajaran sebagai penghubung antara guru dan siswa dalam melakukan proses pembelajaran. Karena media pembelajaran sangat efektif untuk digunakan dalam menyampaikan materi pelajaran (Septiani \& Setyowati, 2020). Penggunaan media pembelajaran untuk pros belajar selama pembelajaran daring sangat bervariasi, mulai dari buku paket, e-book, LKS, modul pembelajaran, zoom, youtobe, google classroom, video penjelasan materi, dan lainlain. Penggunaan media pembelajaran oleh guru dalam mengajarkan materi fisika dapat digambarkan sebagai berikut:

Media apa saja yang biasa digunakan guru Anda dalam mengajrkan materi fisika?

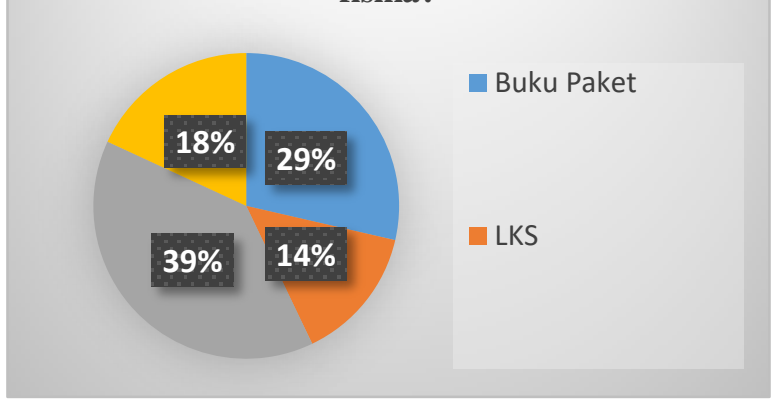

Gambar 3. Diagram penggunaan media dalam pembelajaran fisika oleh guru

Berdasarkan diagram 3, sebanyak 39\% siswa menyatakan guru mengajar menggunakan modul, sebanyak $14 \%$ menyatakan guru menggunakan LKS, dan sebanyak $18 \%$ siswa menyatakan guru mengajar materi fisika menggunakan media pembelajaran lainnya yang bebasis online. Dapat disimpulkan bahwa penggunaan LKS sebagai media pembelajaran masih jarang dilakukan oleh guru. Penggunaan LKS dalam pembelajaran akan memberikan pengalaman belajar yang bermakna bagi siswa, artinya siswa telibat aktif untuk menemukan konsep atau pengetahuan baru kemudian mengatikannya dengan pengetahuan yang ada maupun dengan kehidupan sehari-hari (Asmirani, Putra, \& Asrizal, 2013).

Pembelajaran fisika dikelas tak lepas dari kegiatan eksperimen atau praktikum. Oleh karenanya, dibutuhkan sebuah panduan atau pedoman untuk menuntun siswa dalam melakukan kegiatan tersebut. Penggunaan lembar kerja untuk kegiatan praktikum menjadi salah satu solusi yang dapat ditawarkan untuk mengatasi permasalahan tersebut. Penggunaan lembar kerja untuk melakukan kegiatan praktikum di SMA Negeri 1 Palangka Raya kelas XI dapat digambarkan sebagai berikut: 
Apakah Anda menggunakan lembar kerja untuk kegiatan eksperimen?

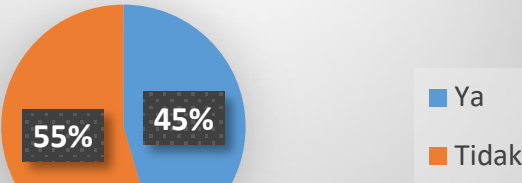

Gambar 4. Penggunaan lembar kerja untuk kegiatan eksperimen

Berdasarkan diagram 4 menunjukkan hasil bahwa $45 \%$ siswa menyatakan menggunakan lembar kerja untuk kegiatan eksperimen, dan sebanyak $55 \%$ siswa menyatakan tidak menggunakan lembar kerja untuk kegiatan eksperimen. Penggunaan lembar kerja untuk kegiatan praktikum dapat membantu dalam memahami kegiatan praktikum di dalam laboratorium (Hadrianti \& Ramiawati, 2018). Lembar kerja tidak hanya berisikan panduan untuk melakukan kegiatan eksperimen, tetapi juga dapat berisi kegiatan diskusi untuk memecahkan permasalahan yang diberikan serta untuk melatih siswa menemukan konsep yang relevan dengan hasil praktikum yang telah mereka lakukan (Fahmidani, Y, Srikandijana, \& A, 2019). Penggunaan lembar kerja berbasis masalah oleh guru untuk siswa kelas XI di SMA Negeri 1 Palangka Raya dapat digambarkan sebagai berikut:

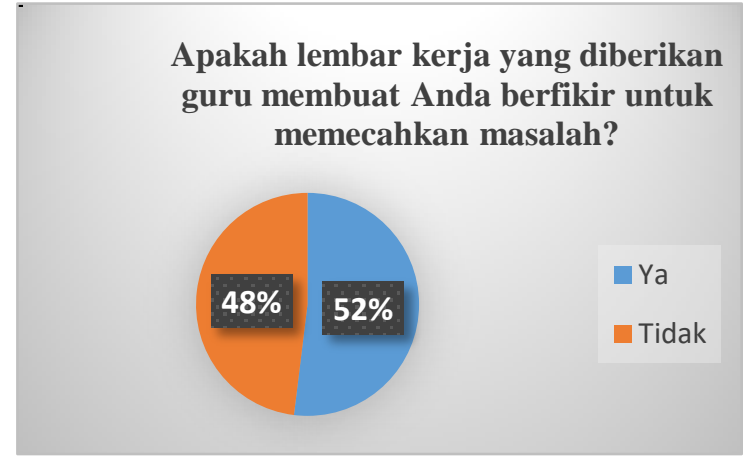

Gambar 5. Penggunaan lembar kerja untuk memecahkan masalah

Berdasarkan Gambar 5 menyatakan bahwa sebanyak 52\% siswa mengatakan lembar kerja yang diberikan guru membuat siswa berfikir untuk memecahkan masalah, dan sebanyak $48 \%$ siswa menyatakan lembar kerja yang diberikan tidak membuat mereka berfikir untuk memecahkan masalah. Penggunaan lembar kerja dalam pembelajaran fisika memiliki kelebihan, diantaranya: meningkatkan hasil belajar siswa ((Fauziah \& Fathiah, 2016); (Indrasati, Indrawati, \& Supiriadi, 2016); (Abelta, Ertikanto, \& I, 2017)); meningkatkan motivasi belajar siswa ( (Indrasati, Indrawati, \& Supiriadi, 2016); (Prasetyawati, Subiki, \& S, 2019)); melatih keterampilan berpikir tingkat tinggi pada siswa ( (Purnamawati, Ertikantro, \& Suyatna, 2017); (Fitriani, Bakri, \& Sunaryo, 2017)); meningkatkan pemahaman konsep ( (Abelta, Ertikanto, \& I, 2017); (Barlenti, Hasan, \& Mahidin, 2017)). Beberapa kelebihan inilah yang menjadikan lembar kerja dianggap sebagai media maupun bahan ajar yang mampu membuat siswa menjadi aktif dalam pembelajaran, tentunya hal ini tidak mengesampingkan peran guru sebagai fasilitator dan motivator dalam pembelajaran.

Kebutuhan siswa akan lembar kerja yang menarik dapat diungkapkan dalam diagram sebagai berikut:

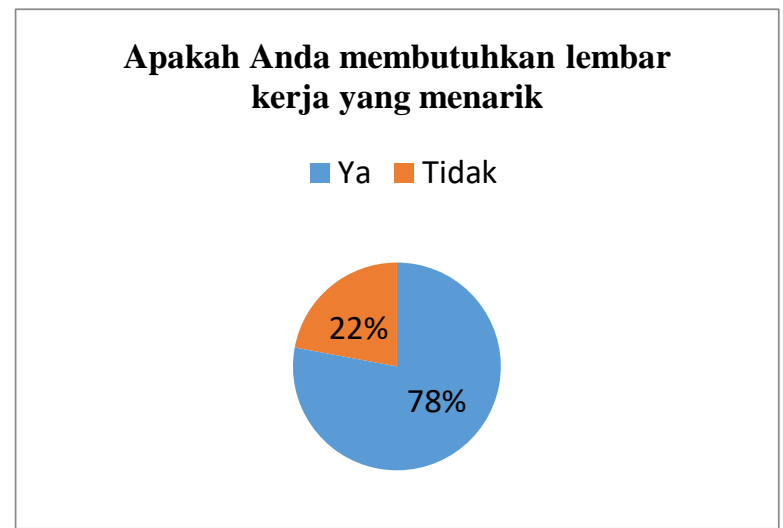

Gambar 6. Diagram respon siswa terhadap pengembangan LKS

Berdasarkan Gambar 6 menunjukkan bahwa $78 \%$ siswa menyatakan membutuhkan lembar kerja yang menarik, dan $22 \%$ lainnya menyatakan tidak membutuhkan lembar kerja. Selain itu kebutuhan siswa akan lembar kerja berbasis masalah di SMA Negeri 1 Palangka Raya untuk kelas XI khususnya materi elastisitas dan hukum Hooke dapat dinyatakan dalam diagram berikut: 
Karst : Jurnal Pendidikan Fisika dan Terapannya Volume 4 | Nomor 1 | 6 p-ISSN: 2622-9641 e-ISSN: 2655-1276

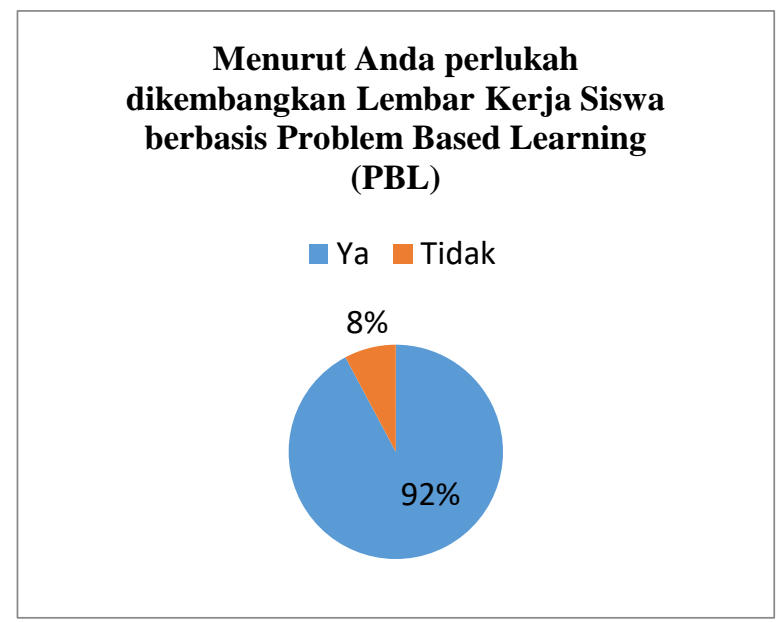

Gambar 7. Respon siswa terhadap pengembangan LKS berbasis PBL

Berdasarkan Gambar 7 menunjukkan bahwa 92\% siswa menyatakan memerlukan pengembangan Lembar Kerja Berbasis Problem Based Learning untuk materi elastisitas dan hukum Hooke, dan sebanyak 8\% siswa menyatakan tidak memerlukan pengembangan LKS berbasis PBL. Pengembangan lembar kerja berbasis masalah dapat membantu siswa memahami materi fisika khususnya materi elastisitas dan hukum Hooke. Untuk membuat lembar kerja yang yang bermanfaat, maka perlu dibuat sebuah bahan ajar yang dapat menarik perhatian bagi siswa sehingga dengan adanya lembar kerja tersebut siswa dapat tertrarik dalam mempelajari materi fisika (Nindyasafitri, Serevina, \& Rustana, 2017) khususnya untuk materi yang berkaitan dengan kehidupan seharihari seperti materi elastisitas dan hukum Hooke.

\section{DAFTAR PUSTAKA}

Abelta, G. A., Ertikanto, C., \& Ismu Wahyudi. 2017. Pengaruh Penggunaan LKS Berbasis Inkuiri Terbimbing Terhadap Hasil Belajar Melalui Pemahaman Konsep. Jurnal Pembelajaran Fisika, V(2).

Asmirani, U., Putra, U., \& Asrizal. 2013. Pengaruh Lks Berbasis Sains Teknologi Masyarakat Terhadap Kompetensi Siswa Dalam Pembelajaran IPA Fisika Di Kelas VII SMPN 1 Kubung Kabupaten Solok. Phillar of Physics Education, 85-90.

Barlenti, I., Hasan, M., \& Mahidin. 2017. Pengembangan LKS Berbasis Project Based Learning Untuk Meningkatkan Pemahaman

\section{PENUTUP}

Berdasarkan hasil survey penyebaran angket online diperoleh beberapa kesimpulan, yaitu:

1. Sistem pembelajaran yang dilakukan saat ini tergolong sulit, dan siswa mengalami beberapa kendala. Kendala pembelajaran yang dialami siswa akhirnya berdampak pada proses pembelajaran siswa khususnya dalam mempelajari materi fisika. Sebanyak 53\% siswa menyatakan mata pelajaran fisika sulit untuk dipalajari, selain banyak rumus sulit dimengerti, sistem pembelajaran daring juga menjadi alasan utama kesulitan siswa dalam memahami materi fisika.

2. Beberapa media pembelajaran yang dipilih guru untuk mengajarkan materi fisika diantaranya adalah: buku paket, LKS, modul, dan aplikasi pembelajaran online lainnya yang menunjang terlaksananya proses pembelajaran. Namun penggunaan LKS oleh guru sebagai media pembelajaran memegang nilai terendah, yaitu sebesar $14 \%$.

3. Sebanyak $74 \%$ siswa tidak mengetahui modul dapat dijadikan sebagai sumber belajar, sebanyak $100 \%$ siswa memerlukan pengembangan e-modul terintegrasi Islam pada materi energi, dan sebanyak $89 \%$ siswa menyatakan bahwa e-modul terintegrasi Islam dapat membantu dalam memahami materi pembelajaran fisika khususnya materi energi.

Konsep. Jurnal Pendidikan Sains Indonesia, $V$ (1).

Cahyadi, R. A. 2019. Pengembangan Bahan Ajara Berbasis ADIE Model. Education Journal, 3543.

Fahmidani, Y., Y, A., Srikandijana, J., \& A, P. A. 2019. Pengaruh Model Pembelajaran Berbasis Masalah Dengan Media Lembar Kerja Terhadap Hasil Belajar Siswa SMA. Chemistry Education Practice, II(1): 1-5.

Fariroh, A., \& Anggraito, Y. U. 2015. Pengembangan Perangkat Pembelajaran Berbasis Problem Based Learning Pada Materi Virus Kelas X 
SMA. Unnes Journal of Biology Education, 4(2), 150.

Fauziah, R., \& Fathiah, S. 2016. Pengaruh Lembar Kerja Siswa Berbasis Mind Map Terhadap Hasil Belajar Siswa Pada Konsep Fluida Statis. EDUSAINS, VIII(2).

Fitriani, W., Bakri, F., \& Sunaryo. (2017). Pengembangan Lembar Kerja Siswa (LKS) Fisika Untuk Melatih Kemampuan Berpikir Tingkat Tinggi (High Order Thinking Skill) Siswa SMA. Jurnal Wahana Pendidikan Fisika, II(1).

Hadrianti, S., \& Ramiawati. (2018). Pengembangan Lembar Kerja Peserta Didik ( LKPD ) BerorientasiKeterampilan Generik Sains untuk Meningkatkan Hasil Belajar IPA Peserta Didik. Jurnal Pendidikan Sains Indonesia (Indonesian Journal of Science Education), 24-31.

Ikhsan, A., Sulaiman, \& Ruslan. (2017). Pemanfaatan Lingkungan Sekolah Sebagai Sumber Belajar di SD negeri 2 Teunom Aceh Jaya. Jurnal Ilmiah Pendidikan Guru Sekolah Dasar, 1-11.

Indrasati, H., Indrawati, \& Supiriadi, B. (2016). Pengaruh Model Quantum Teaching Diserta LKS Berbasis Kartun Fisika Terhadap Hasil Dan Motivasi Belajar Siswa Dalam Pembelajaran Fisika Di SMA. Jurnal Pembelajaran Fisika, V(1).

Kristiantari, M. R. (2014). Analisis Kesiapan Guru Sekolah Dasar Dalam Mengimplementasikan Pembelajaran Tematik Integratif Menyongsong Kurikulum 2013. Jurnal Pendidikan Indonesia, III(2), 461.

Mastang, M. 2017. Pengembangan Perangkat Pembelajaran Berbasis Problem Based Learning Kelas X MIA SMA Muhammadiyah Limbung. Makassar: Universitas Islam Alauddin.

Meiwandari, M. 2020. Pengembangan Perangkat Pembelajaran IPA SMP Kelas VIII Berbasis Keterampilan Berpikir Kritis. Palembang: Universitas Sriwijaya.

Mulyasa, E. 2014. Pengembangan dan Implementasi Kurikulum 2013. Bandung: PT Remaja Rosdakarya.

Mustafa, P. S., \& Dwiyogo, W. D. 2020. Kurikulum Pendidikan Jasmani, Olahraga, dan Kesehatan di Indonesia Abad 21. Jurnal Riset Teknologi dan Inovasi Pendidikan, III(2), 423.

Nindyasafitri, F., Serevina, V., \& Rustana, C. E. 2017. Pengembangan LKS Berbasis PBL
(Problem Based Learning) Pada Pokok Bahasan Momentum dan Impuls Fisika SMA Kelas XI. Jurnal Wahana Pendidikan Fisika, 51-57.

Permana, P. D. 2015. Pengaruh Penerapan Kurikulum 2013 Terhadap Hasil Belajar Mata Diklat Pengelasan Kelas X TKR di SMK Negeri 1 Sedan Rembang Tahun Ajaran 2013/2014. Semarang: Universitas Negeri Semarang.

Prasetyawati, I. W., Subiki, \& S, B. A. 2019. Pengaruh LKS Berbasis Inkuiri Terbimbing Disertai Permainan Ular Tangga Terhadap Motivasi Dan Hasil Belajar Siswa SMA Di Kabupaten Jember. Jurnal Pembelajaran Fisika, VIII(3).

Purnamawati, D., Ertikantro, C., \& Suyatna, A. 2017. Keefektifan Lembar Kerja Siswa Berbasis Inkuiri Untuk Menumbuhkan Keterampilan Berpikir Tinggi. Jurnal Ilmiah Pendidikan Fisika Al-Biruni, VI(2), 209-219.

Putri, S. D., \& Djamas, D. 2017. Pengembangan Perangkat Pembelajaran FIisika Berbasis Keterampilan Berpikir Kritis Dalam Problem Based Learning. Jurnal Ilmiah Pendidikan Fisika Al-BiRuNi, VI(1), 126.

Rukajat, A. 2018. Pendekatan Penelitian Kuantitatif: Quantutative Research Approach. Yogyakarta: CV Budi Utomo.

Septiani, E., \& Setyowati, L. 2020. Penggunaan Media Pembelajaran Secara Daring Terhadap Pemahaman Belajar Mahasiswa. Prosiding Seminar Nasional Pascasarjana Universitas Negeri Jakarta (pp. 121-128). Jakarta: Universitas Negeri Jakarta.

Wiliyanti, V., Suyanto, E., \& Abdurrahman. 2014. Pengembangan Perangkat Pembelajaran IPA Terpadu Berorientasi Pendidikan Karakter Pada Model Pembelajaran Exclusive. Jurnal Pembelajaran Fisika, 132.

Winarno. 2012. Pengembangan Karakter Bangsa Melalui Pendidikan Jasmani dan Olahraga. Sidang Senat Terbuka Universitas Negeri Malang (p. 4). Malang: Universitas Negeri Malang.

Zaini, H. (2015). Karakteristik Kurikulum 2013 dan Kurikulum Tingkat Satuan Pendidikan (KTSP). Jurnal Idaroh, I(1), 16. 